\title{
RIGIDITAS HARGA-UPAH DAN IMPLIKASINYA PADA KEBIJAKAN MONETER DI INDONESIA
}

\author{
Solikin dan Iman Sugema ${ }^{1}$
}

\begin{abstract}
Abstraksi
This research is using survey method with focusing on the issue of how and what the determinants of price and wage rigidity, including uncertainty.

In the case of price rigidity, we find that firm-cost related factors or supply side plays greater role than demand side of the market. This rule applies on middle up scale firm, firm with differentiated products and firm with large market coverage. The opposite will occur on small, homogenous product and small market coverage firm. We also confirm the downward rigidity phenomenon as price is ease to increase than decrease.
\end{abstract}

Our findings imply several important impact on monetary policy effectiveness, monetary policy asymmetry, inflation-targeting and minimum wage determination.

Keywords: Price rigidity, wage rigidity

JEL: E31, E52, J31

1 Solikin adalah Peneliti Ekonomi di Pusat Pendidikan dan Studi Kebanksentralan (PPSK) - Bank Indonesia. Iman Sugema adalah Ekonom Senior INDEF, solikin@ bi.go.id 


\section{PENDAHULUAN}

Dalam periode krisis ekonomi yang telah berjalan selama lima tahun terakhir, kita dapat menyaksikan lonjakan harga secara tajam, terutama pada tahun 1998. Pada tahun tersebut tingkat inflasi mencapai 57 persen atau kira-kira delapan kali tingkat inflasi ratarata sebelum krisis. Puncak inflasi terjadi pada bulan September 1998, yaitu sekitar 82 persen. Pada tahun berikutnya keadaan ini berbalik menjadi deflasi. Selama dua tahun terakhir tingkat inflasi kembali normal seperti sebelum krisis.

Inflasi secara harfiah didefinisikan sebagai pergerakan kenaikan harga secara umum. Dengan kata lain inflasi mencerminkan kenaikan harga barang-barang konsumsi secara menyeluruh, walaupun tingkat kenaikan harga di masing-masing komoditi secara relatif berbeda satu dengan yang lainnya. Dengan demikian, pemahaman tentang dinamika pembentukan harga di level mikro atau di tingkat komoditi dan sektor akan sangat membantu dalam memahami pola pergerakan harga secara umum.

Sebagai salah satu indikator kunci yang diperhitungkan dalam pencapaian target kebijakan moneter dengan sasaran tunggal stabilitas harga, perilaku dinamis inflasi (inflation dynamic) merupakan fenomena yang strategis, sekaligus kompleks - baik dilihat dari aspek struktural maupun moneter - untuk dipelajari. Hal ini mengingat perilaku dinamis inflasi mengakomodir pola perkembangan variabel-variabel ekonomi di sisi permintaan dan penawaran, respon kebijakan moneter, maupun perilaku kelembagaan. Dengan demikian, dengan memahami perilaku variabel-variabel ekonomi makro utama, khususnya harga (inflasi), pelaksanaan, pengendalian, dan assessment terhadap kinerja kebijakan moneter (transmisi kebijakan moneter) dapat dilakukan dengan efektif.

Perdebatan mengenai permasalahan inflasi di beberapa negara kebanyakan diwarnai oleh perhatian lebih pada arah perkembangan dari variabel-variabel utama lain yang terkait, misalnya upah (gaji), produktivitas, keuntungan kegiatan dunia usaha (bisnis), dan kesempatan kerja. Terdapat kecenderungan bahwa tekanan inflasi yang tinggi akan mendorong variabel-variabel tersebut berubah secara serentak. Dengan kondisi tersebut serta sejalan dengan kompleksitas mata rantai hubungan antara beberapa variabel terkait, sangatlah sulit untuk mengamati perilaku pembentukan harga secara spesifik serta keterkaitan strukturalnya dengan perilaku pembentukan variabel utama lainnya, dalam hal ini upah. Sulitnya pengamatan terhadap perilaku kedua variabel tersebut juga berkaitan dengan sulitnya mengidentifikasi/ memprediksi sumber-sumber gejolak struktural (shocks) yang memicu tekanan inflasi, terutama dikaitkan dengan rentannya perilaku kelembagaan (berkaitan dengan kebijakan harga dan upah minimum regional) serta peningkatan peran/ keberadaan serikat pekerja dalam mempengaruhi pembentukan upah. 
Sementara itu, dari sisi lain, perdebatan mengenai sumber shocks yang menyebabkan fluktuasi kegiatan dunia usaha (business cycle analysis) juga menempatkan peranan dari perilaku dinamis harga dan upah sebagai variabel kunci. Hal ini berkaitan dengan pengaruh keberadaan uang dalam perekonomian (money neutrality); apakah uang bersikap netral atau tidak. Seperti diketahui, ekonom Keynesian beranggapan bahwa perilaku harga dan upah nominal adalah tidak begitu fleksibel atau bersifat kaku (rigid). ${ }^{2}$ Dengan asumsi tersebut maka setiap perubahan permintaan agregat (nominal disturbances) dianggap mempunyai dampak terhadap fluktuasi output riil. Bila perubahan permintaan agregat tersebut juga mencerminkan perubahan searah dari besaran-besaran moneter (misal uang beredar) maka hal ini berarti, kebijakan moneter dapat secara efektif diarahkan untuk mempengaruhi perkembangan variabel-variabel ekonomi riil, sehingga uang bersifat tidak netral (nonneutrality of money).

Beberapa studi mengenai perilaku pembentukan harga dan upah (secara simultan) telah banyak dilakukan di beberapa negara, yang umumnya dengan menggunakan pendekatan ekonometrik/makro dan data agregat. Keterbatasan dari studi agregatif tersebut umumnya berkaitan dengan adanya permasalahan spesifikasi model, misalnya serial correlation of residuals dan large sampling errors. Sementara itu, studi serupa jarang/belum dilakukan untuk kasus Indonesia. Salah satu studi terkini mengenai perilaku pembentukan harga oleh Bank Indonesia mengetengahkan pendekatan survei. ${ }^{3}$ Studi yang dilakukan dari sisi kegiatan dunia usaha ini menyimpulkan bahwa inflasi di Indonesia pada lebih disebabkan oleh dorongan biaya (cost-push), yang umumnya dipicu oleh kenaikan administered price, pajak, upah minimum, dan depresiasi rupiah. Sementara itu, tekanan sisi permintaan tidak begitu kuat, kecuali pada perayaan hari besar keagamaan. Keterbatasan studi tersebut - dari pokok-pokok kesimpulan - lebih disebabkan oleh cakupan survei yang lebih diarahkan pada pelaku kegiatan usaha di sektor industri manufaktur dan retail yang lebih merepresentasikan perilaku sisi penawaran. Selain itu, penelitian tersebut belum menyinggung secara nyata salah satu isu penting, yaitu masalah kekakuan (rigidity).

Dengan mengacu pada beberapa isu strategis serta hasil studi yang telah dilakukan, penelitian yang didukung oleh pendekatan survei ini ditujukan untuk meneliti perilaku pembentukan harga dan upah. Manfaat dari penelitian ini, selain diharapkan dapat memperlengkapi hasil penelitian yang telah dilakukan sebelumnya, juga untuk mendukung

2 Beberapa kajian mendalam dilakukan untuk menjelaskan kekakuan tersebut, namun lebih mengarah pada teori kekakuan riil, bukan nominal; yaitu menjelaskan mengapa harga dan upah riil tidak begitu responsif terhadap perkembangan kegiatan ekonomi. Perlu dikemukakan bahwa tanpa adanya sumber penyebab yang bersifat independen dari kekakuan nominal tersebut, harga akan merepons sepenuhnya shocks nominal yang terjadi; tidak bergantung terhadap seberapa besar kekakuan riil yang terjadi. Dengan demikian kekakuan riil tidak selalu berimplikasi pada kekakuan nominal.

3 Lihat "Survey on Business Price Setting Behaviour", Bagian SSR-DKM Bank Indonesia, 2002. 
analisis mengenai efektifitas pelaksanaan, pengendalian, dan assessment terhadap kinerja kebijakan moneter (transmisi kebijakan moneter) dengan target tunggal stabilitas rupiah (harga). Adapun tujuan penelitian akan difokuskan untuk meneliti isu pokok, yaitu sampai sejauhmana dan faktor-faktor apa saja yang mempengarughi derajat rigiditas dari perilaku harga dan upah dalam merespon shocks dari sisi permintaan dan penawaran (termasuk dengan adanya unsur ketidakpastian). Secara teknis, hal tersebut diharapkan dapat menjawab beberapa pokok permasalahan yang terkait, yaitu : (i) Bagaimana pola penyesuaian dan derajat rigiditas harga dan upah yang terjadi; (ii) Bagaimana pengaruh dinamika pasar tenaga kerja terhadap perilaku harga dan upah ; dan (iii) Sejauhmana pengaruh ekspektasi masyarakat (backward/forward) dalam pembentukan harga dan upah.

Kajian ini akan disampaikan dalam enam bagian. Menyambung bagian pendahuluan ini akan disampaikan kerangka teoritis mengenai bagaimana rigiditas harga dan upah berpengaruh terhadap perkembangan output dan pelaksanaan kebijakan moneter serta faktor-faktor yang mempengaruhi rigiditas tersebut. Selanjutnya, pada bagian tiga akan dipaparkan kerangka analisis dan metodologi, khususnya yang terkait dengan pelaksanaan survei. Sebelum penarikan kesimpulan dan implikasi kebijakan, hasil analisis mengenai pembentukan dan rigiditas harga-upah akan dikemukakan dengan mendasarkan hasil survei. Tulisan ini ditutup oleh penyampaian beberapa kesimpulan dan implikasi kebijakan.

\section{KERANGKA TEORITIS}

Berdasarkan beberapa hasil studi empiris, ditemukan bahwa harga di Indonesia bersifat rigid ke bawah (down ward rigidity). Secara teoritis fenomena ini bisa diterangkan melalui dua pendekatan yaitu: rigiditas di pasar output dan di pasar input. Dalam aliran Keynesian, rigiditas di pasar output lebih sering diterangkan melalui mekanisme menu cost dan monopolistic competition. Rigiditas di pasar input bisa didekati dengan berbagai teori tentang rigiditas upah baik secara nominal maupun secara riil.

Dinamika pembentukan harga dan upah itu sendiri sangat menentukan bagaimana pengambilan keputusan dalam kebijakan moneter seperti tingkat suku bunga, jumlah uang yang beredar dan inflasi berpengaruh terhadap perekonomian. Berdasarkan teori klasik, variabel-variabel moneter tidak memiliki pengaruh terhadap variabel riil. Teori ini didasarkan pada anggapan bahwa perubahan harga terjadi secara instan dan tanpa biaya (costless). Akan tetapi bagi orang yang terbiasa membeli atau menjual barang akan tahu bahwa dalam kenyataannya harga ditentukan oleh penjual dan pembeli dan perubahan harga memerlukan waktu serta biaya. Untuk menghitung tingkat harga yang tepat, serta bagaimana harga harus merespon terhadap perubahan pasar, seringkali hal ini melibatkan suatu proses yang tidak mudah dilakukan. 
Sampai saat ini terdapat banyak fakta yang menunjukkan bahwa perubahan dalam jumlah uang yang beredar dan harga dapat mempengaruhi output dan kesempatan kerja setidaknya dalam jangka pendek. Temuan yang terpenting dalam kasus ini adalah temuan oleh Friedman dan Schwartz (1963) dan setelah itu banyak peneliti-peneliti lainnya berusaha untuk menyempurnakan dan mengkonfirmasikan temuan tersebut. Bagi ekonom Keynesian, fenomena ini tidaklah merupakan hal baru. Hal tersebut bisa diterangkan melalui berbagai teori yang mengasumsikan adanya rigiditas dalam pembentukan harga dan upah. Rigiditas tersebut menyebabkan perubahan-perubahan dalam kebijakan moneter dapat secara efektif berpengaruh terhadap variabel-variabel riil. Jadi uang bersifat tidak netral (non neutrality of money) setidaknya dalam jangka pendek.

\section{II.1. Sumber Rigiditas Harga:Review Beberapa Literatur}

Saat ini terdapat berbagai macam model dan teori yang memasukkan faktor rigiditas harga. Setidaknya rigiditas harga dapat ditinjau baik dari sudut nominal maupun riil. Pada intinya apapun bentuk rigiditas yang secara aktual terjadi, implikasinya adalah tetap sama, yaitu bahwa kebijakan moneter dapat secara efektif digunakan untuk mempengaruhi keseimbangan output dan kesempatan kerja.

Model yang paling banyak digunakan sebagai basis untuk menerangkan rigiditas harga adalah model persaingan monopolistik yang dikembangkan oleh Blanchard dan Kiyotaki (1987). Dalam model ini diasumsikan bahwa terdapat banyak produsen yang memproduksi barang-barang yang tidak bersubstitusi satu sama lain secara sempurna (imperfect substitution), dan tidak ada bahan baku yang dibeli.Produsen juga bertindak sebagai konsumen yang berusaha memaksimumkan utilitasnya dengan mengkonsumsi barangbarang dan uang (riil) yang telah ada dalam fungsi utilitasnya. Permintaan agregat nominal hanya tergantung pada jumlah uang beredar nominal. Biaya marginal dinyatakan sebagai marginal disutility of production. Dengan asumsi constant return dan constant marginal disutility of work maka marginal cost bersifat horisontal sementara kurva permintaan memiliki elastisitas yang konstan. Produsen bereaksi terhadap perubahan permintaan sepenuhnya dengan melakukan perubahan jumlah output, tetapi harga relatif tetap konstan.

Model S,s lump sum cost adalah suatu pendekatan dimana penyesuaian harga yang dilakukan oleh suatu pesaing monopolis yang memaksimumkan keuntungan sangat tergantung pada besarnya lump sum cost. Model ini dibangun oleh Barro (1972), dan pada dasarnya model $S$,s diturunkan dari perilaku monopoli yang menghadapi kejutan-kejutan dalam permintaan yang bersifat random. Strategi optimal yang dilakukan oleh perusahaan monopolis tersebut adalah membuat bentangan batas atas dan batas bawah dimana harga 
bersifat konstan selama keseimbangan pasar berada di dalam bentangan tersebut. Perubahan harga hanya akan dilakukan jika kondisi keseimbangan menembus batas atas atau batas bawah dari bentangan tersebut. Pengembangan selanjutnya terhadap model ini oleh Sheshinki dan Weiss $(1977,1983)$ menunjukkan bahwa penyesuaian harga seperti ini membawa implikasi bahwa penyesuaian harga secara agregat juga akan bersifat lamban. Jadi selama tidak ada kebijakan yang drastis misalnya perubahan jumlah uang yang beredar secara besar-besaran maka tingkat inflasi dapat dikendalikan.

Sebagai metafor, Mankiw (1985) menggunakan menu $\operatorname{cost}^{4}$ yang walaupun hanya merupakan komponen yang kecil terhadap total biaya perusahaan ternyata mampu menahan produsen untuk tidak melakukan perubahan harga. Dalam persaingan monopolistic, tingkat harga ditentukan oleh price setter. Masalahnya adalah bahwa, penurunan harga mungkin akan membawa manfaat sosial yang besar tetapi manfaat yang diperoleh perusahaan individual yang bersaing secara monopolistic biasanya sangat kecil. Karena itu, walaupun menu cost yang dihadapi tergolong kecil, perusahaan tidak memiliki insentif untuk menurunkan harga. Pada gilirannya, semua pesaing mematok harga pada tingkat yang sama dengan sebelumnya walaupun terjadi penurunan permintaan.

Selain sumber dari rigiditas harga adalah adanya kontrak jual beli barang baik secara eksplisit maupun secara implisit. Dalam model yang dikembangkan oleh Blanchard (1983, 1986) dan Ball dan Romer (1989), penentuan harga oleh masing-masing perusahaan dilakukan untuk jangka waktu interval kontrak yang saling over lapping dan revisi harga tersebar sepanjang interval kontrak (staggered contract). Ball dan Romer (1989) menunjukkan bahwa staggering bisa merupakan keseimbangan yang stabil jika terjadi shock secara random dan spesifik terhadap masing-masing perusahaan monopolis. Tetapi mereka juga menemukan bahwa sinkronisasi dapat merupakan keseimbangan yang relatif stabil. Keseimbangan ganda seperti ini bisa terjadi jika ada insentif untuk melakukan sinkronisasi dalam arti bahwa semua perusahaan ingin tetap terikat sebagai suatu kelompok. Dalam konteks yang lebih umum, penyesuaian harga secara serempak dan merata tidak mungkin terjadi jika shock bersifat spesifik perusahaan. Tetapi perubahan yang serempak hanya mungkin terjadi jika shock dipandang dapat mempengaruhi semua perusahaan atau dengan kata lain shock-nya berlaku umum.

Okun (1975) mempopulerkan perbedaan antara pasar pelanggan dan pasar lelang ala Walras. ${ }^{5}$ Dalam model pasar pelanggan, search bersifat costly sehingga pelanggan

4 Menu cost dapat diartikan disini sebagai biaya -biaya yang harus dikeluarkan oleh produsen bila melakukan perubahan harga,misalnya biaya mencetak price list baru, biaya mengubah strategi pemasaran, biaya mengumpulkan informasi tentang kondisi pasar dll.

5 Model Okun didasarkan pada model yang dikembangkan oleh Alchian (1969) dan Phelps dan Winter (1970). 
bersedia membayar premium. Selain itu kemungkinan berpindahnya pelanggan akan menyebabkan perusahaan tidak memiliki insentif untuk mengubah harga sebagai respon terhadap perubahan permintaan dalam jangka pendek. Okun mengemukakan bahwa model search seperti ini juga dapat menerangkan praktek penentuan harga berdasarkan biaya plus mark up. Konsumen diasumsikan dapat menerima kenaikan harga yang disebabkan oleh terjadinya kenaikan biaya produksi secara permanen. Akan tetapi perubahan-perubahan yang bersifat sementara seperti kenaikan permintaan dan penurunan produktivitas tidak bisa diharapkan sebagai alasan penyesuaian harga.Dalam model ini konsumen tidak merespon secara instan terhadap perubahan dalam harga riil atau harga relatif.

Dalam model Okun di atas ada satu hal yang menarik yaitu terjadinya pemisahan antara biaya dan permintaan. Pemisahan antara biaya dan permintaan seperti ini membuka kemungkinan bahwa perubahan dalam marginal cost terisolasi dari perubahan permintaan (marginal reveneu). Bertola dan Caballero (1990) menegaskan bahwa ketidakpastian merupakan satu alasan pokok mengapa perubahan harga tidak sering terjadi. Pembedaan atas shock yang bersifat lokal dan yang bersifat agregat bisa menjadi dasar untuk menerangkan mengapa perubahan dalam marginal cost dapat berbeda arah dengan perubahan dalam marginal revenue. Contohnya adalah sebagai berikut. Pertama, marginal revenue dapat berubah sesuai dengan perubahan permintaan agregat nominal, tetapi mungkin marginal cost tidak berubah. Kedua, dalam situasi dimana tidak terjadi perubahan permintaan agregat, perusahaan dapat saja menghadapi penurunan permintaan lokal sementara biaya marginal tetap. Pada intinya kita dapat memilah-milah apakah shock terjadi secara lokal atau agregat atau terhadap sisi permintaan atau penawaran.

\section{II.2. Sumber Rigiditas Upah: Review Beberapa Literatur}

Penelitian untuk mencari alasan terjadinya mekanisme non Walrasian banyak yang terfokus pada pasar tenaga kerja. Keynes sendiri mengajukan alasan bahwa hal tersebut terjadi karena penyesuaian tingkat upah berjalan secara lamban. Trik yang paling mendasar dalam menerangkan kenapa upah sangat lamban untuk disesuaikan adalah bahwa perusahaan dan pekerja sama-sama terikat oleh suatu kontrak ketenagakerjaan yang memuat tingkat upah nominal yang akan dibayarkan (Gray 1976, Fischer 1977, dan Taylor 1980). Salah satu keunggulan dari cara pemodelan seperti ini bahwa hal ini merefleksikan setting kelembagaan yang berlaku umum. Karena upah nominal bersifat rigid, maka shock permintaan agregat akan mengubah keseimbangan output dan tenaga kerja. Oleh karenanya, policy irrelevance ala Sargent-Wallace tidak berlaku dalam model seperti ini. 
Karena, argumen nominal rigidity mengundang banyak kritik, Keynesianist mengarahkan argumen mereka pada pendekatan real rigidities dimana upah riil tidak dapat disesuaikan untuk menyeimbangkan pasar tenaga kerja. Pendekatan yang paling populer digunakan untuk menerangkan real rigidities adalah barangkali pendekatan efficiency wage, yaitu tingkat upah yang diberikan oleh perusahaan untuk mempertahankan pekerja dengan tingkat produktivitas tinggi. Model seperti ini dibangun berdasarkan tulisan Yellen (1984), Bullow dan Summers (1986) dan Stiglitz (1986). Terjadinya real rigidity setidaknya dapat dijelaskan dengan tiga alasan berikut. Pertama, alasan sosiologis, pekerja yang dibayar rendah cenderung kurang loyal. Kedua, teori adverse selection meramalkan bahwa penurunan tingkat upah akan menurunkan kualitas rata-rata pekerja karena pekerja yang terbaik yang akan keluar dari perusahaan. Ketiga, turunnya tingkat upah akan mengakibatkan rendahnya opportunity cost of getting fired yang pada gilirannya akan meningkatkan terjadinya shirking tanggung jawab. Penelitian yang dilakukan oleh Ball dan Romer (1990) menunjukan bahwa menu cost dan real rigidity merupakan dua pendekatan yang saling komplementer. Menu cost mencegah perusahaan untuk menurunkan harga walaupun terjadi penurunan permintaan agregat. Efficiency wage mencegah perusahaan untuk memanfaatkan kelebihan penawaran tenaga kerja dengan menurunkan tingkat upah sehingga biaya produksi tetap tinggi. Pada gilirannya tingginya biaya produksi menjadi alasan yang kuat untuk tidak menurunkan harga output.

Model yang dibangun oleh Mc Donald dan Solow (1981) yang menunjukkan bahwa dengan terjadinya monopoli bilateral antara perusahaan dan serikat buruh, maka keseimbangan yang terjadi akan berasosiasi dengan fluktuasi kesempatan kerja tetapi upah riil relatif stabil dengan demikian model seperti ini bisa dianggap sebagai salah satu alasan terjadinya rigiditas upah riil. Jika upah ditentukan melalui kontrak yang ditandatangani antara serikat buruh dan perusahaan, maka marginal cost dan harga output akan bersifat rigid. Tentunya hal ini mengakibatkan fluktuasi dalam permintaan akan ditransmisikan secara langsung dalam bentuk fluktuasi output dan kesempatan kerja.

Salah satu teori yang bisa menerangkan mengapa terjadi pengangguran secara persisten adalah teori insider dan outsider. Insider adalah pekerja yang posisinya terproteksi oleh berbagai macam biaya turn overyang menyebabkan perusahaan cenderung enggan untuk melepas mereka. Lindbeck dan Snower (1986-1988) mengungkapkan bahwa karena adanya biaya turn over, insider memperoleh kekuatan pasar yang menyebabkan mereka berada pada posisi yang lebih diuntungkan dibanding outsider. Selain itu insider juga dapat mempengaruhi biaya turn over melalui kerjasama diantara mereka untuk menyisihkan kepentingan outsider, walaupun outsider bisa menerima upah yang lebih rendah. Dengan struktur semacam ini outsider akan tetap menganggur walaupun mereka rela menerima upah yang lebih rendah dibandingkan insider. 


\section{II.3. Hubungan antara Perilaku Harga dan Upah}

Pada umumnya New Keynesian memandang bahwa rigiditas nominal memiliki origin di pasar produk dan bukannya di pasar tenaga kerja. Mankiw (1988), Barro (1977) dan Hall (1980) berargumen bahwa rigiditas upah tidak relevan dalam menentukan tingkat kesempatan kerja. Argumen di atas tentunya tidak sepenuhnya benar karena hal tersebut memiliki implikasi bahwa harga harus bersifat fleksibel sempurna untuk menjamin terjadinya market clearing. Dalam kasus persaingan monopolistik agar harga bersifat fleksibel sempurna maka marginal cost juga harus fleksibel sempurna. Dengan kata lain, agar prediksi Mankiw, Barro dan Hall bisa benar bahwa rigiditas upah adalah tidak relevan maka upah nominal harus diindeksasi.

Sebagaimana halnya adalah tidak masuk akal bahwa upah bersifat kaku sedangkan harga bersifat fleksibel, maka sebaliknya juga adalah tidak masuk akal bahwa upah bersifat fleksibel sedangkan harga bersifat kaku. Inilah salah satu kelemahan asumsi dalam model menu cost. Supaya suatu model New Keynesian dapat menghindari inkonsistensi seperti di atas, prinsip dasar menu cost dalam pasar produk juga seharusnya berlaku untuk pasar tenaga kerja. Perlakuan yang sama dalam biaya penyesuaian yang menghambat terjadinya perubahan harga juga seharusnya berlaku sebagai penghambat dalam penyesuaian upah. Rigiditas harga menyebabkan perubahan dalam permintaan agregat diterjemahkan sebagai pergeseran kurva permintaan yang tidak hanya dihadapi oleh produsen tetapi juga oleh buruh.

\section{METODE PENELITIAN}

Fokus dalam studi ini adalah untuk menerangkan fenomena rigiditas harga dan upah, dan karenanya survei akan diarahkan untuk mengetahui mekanisme penentuan harga dan upah di level perusahaan manufaktur, perdagangan besar dan perdagangan eceran. Untuk sektor manufaktur survei dilakukan untuk mengungkap rigiditas upah dan harga, sedangkan di sektor ritel dan perdagangan besar hanya berkaitan dengan mekanisme penentuan harga. Pemilihan sektor manufaktur disebabkan oleh beberapa alasan berikut ini. Dalam survei ini, 220 perusahaan yang memproduksi barang-barang konsumsi dijadikan responden. Pada umumnya perusahaan manufaktur tersebut berlokasi di kota besar di Indonesia: Jabotabek, Surabaya, Bandung, Semarang dan Medan. Survei ini meliputi 541 merk dagang dari berbagai macam jenis produk. Perusahaan-perusahaan tersebut dapat dikelompokkan ke dalam delapan sub sektor yang meliputi 194 jenis barang. 
Statistik deskriptif akan digunakan sebagai alat analisis untuk: (a) price setting stance, (b) wage setting stance, (c) identifikasi faktor-faktor yang mempengaruhi perubahan harga, (d) rigiditas upah dan harga.

Price setting stance meliputi:

- Biaya langsung ditambah mark up

- Kondisi pasar

- Pangsa pasar

- Penentuan harga oleh pembeli

- Regulasi

Wage setting stance meliputi:

- Explicit contract

- Implicit contract

- Individual bargaining

- Efficiency wage

- Union bargaining

- Regulation

Faktor-faktor yang mempengaruhi perubahan harga:

- Perubahan biaya produksi (harga bahan baku, suku bunga, nilai tukar)

- Perubahan permintaan (income, inflasi, perubahan demografis)

- Perubahan produktivitas

- Perubahan harga kompetitor

- Perubahan pangsa pasar

- Perubahan regulasi

- Faktor musiman (hari besar, paceklik)

Faktor-faktor yang menyebabkan terjadinya perubahan upah:

- Profit

- Productivity

- Regulation 
- Cost of living

- Periodic adjustment

- Union bargaining

Rigiditas harga meliputi:

- Cost base pricing

- Implicit contract

- Explicit contract

- Pro-cyclical elasticity

- Pricing threshold

- Non-price element

- Stock adjustment

- Coordination failure

- Price means quality

- Physical menu cost

Rigiditas upah disebabkan oleh:

- Explicit contract

- Implicit contract

- Efficiency wage

- Regulation

- Insider-outsider

- Relative wage

- Menu cost

- Non-wage adjustment

Skema pengupahan terdiri dari:

- Fixed wage

- Variable wage

- Hourly/daily

- Basic sallary + incentive 


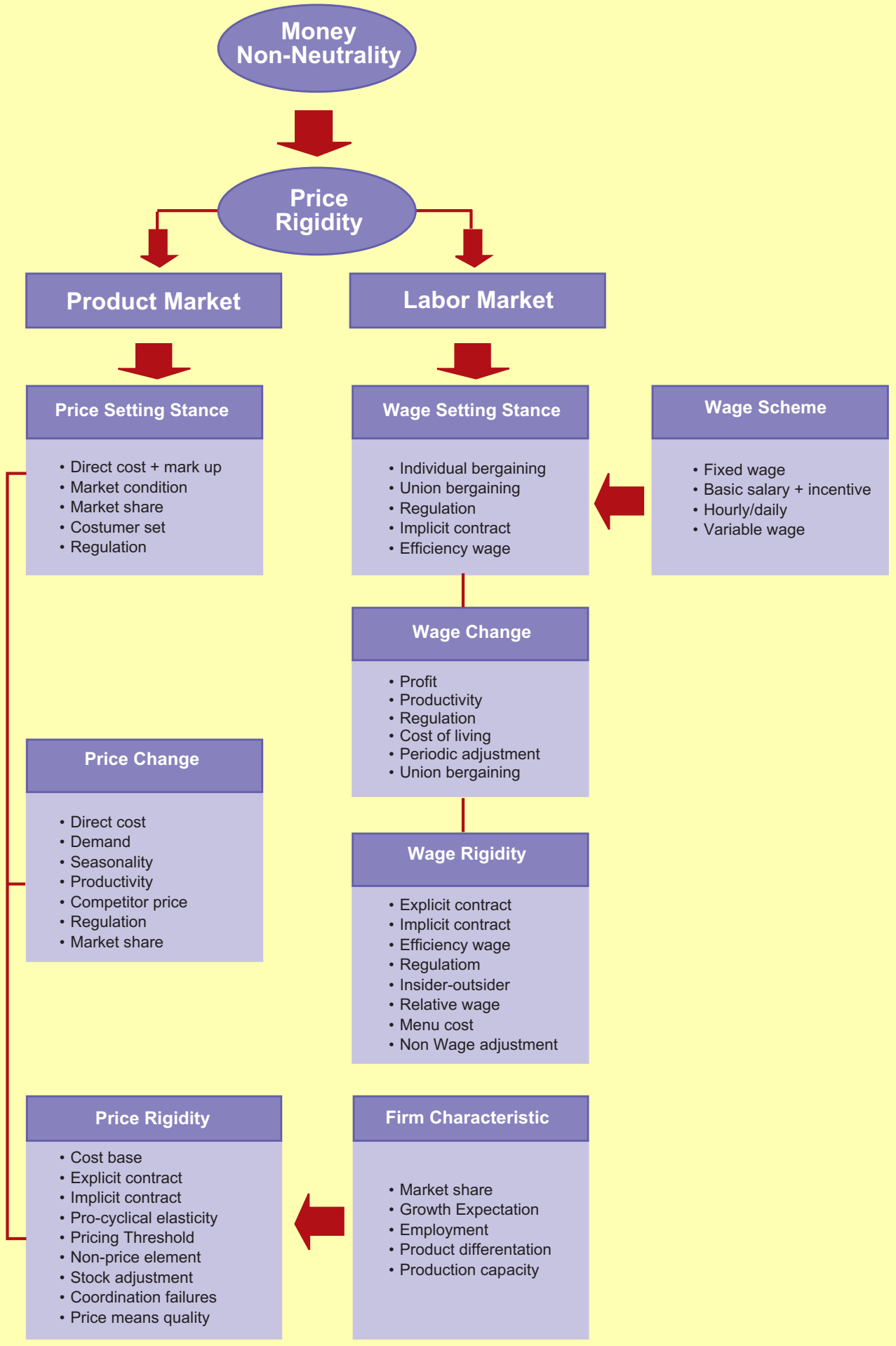




\section{DINAMIKA PEMBENTUKAN DAN RIGIDITAS HARGA}

\section{IV.1. Cara Penentuan Harga}

Bagian pertama dari survey Bank Indonesia adalah mengajukan pertanyaan kepada perusahaan dan pedagang untuk mengidentifikasi faktor-faktor apa saja yang menentukan dalam proses pembentukan harga. Gambar 4.1. dan Tabel 4.1. menyarikan hasil dari survey tersebut. Secara umum bisa dikatakan bahwa faktor-faktor yang menyangkut biaya perusahaan atau sisi supply jauh lebih berperan dalam penentuan harga dibanding kondisi pasar atau sisi demand.

Pentingnya sisi supply ditunjukkan dengan kenyataan bahwa lebih dari 50 persen perusahaan yang harganya ditentukan berdasarkan perhitungan atas biaya langsung ditambah mark up yang bersifat variable. Di samping itu, terdapat sekitar 16 persen perusahaan responden menyatakan bahwa harga dihitung berdasarkan besarnya biaya langsung ditambah mark up tetap. Kenyataan ini menunjukkan bahwa harga memiliki peluang lebih besar untuk berubah jika terjadi perubahan-perubahan dalam struktur ongkos perusahaan.

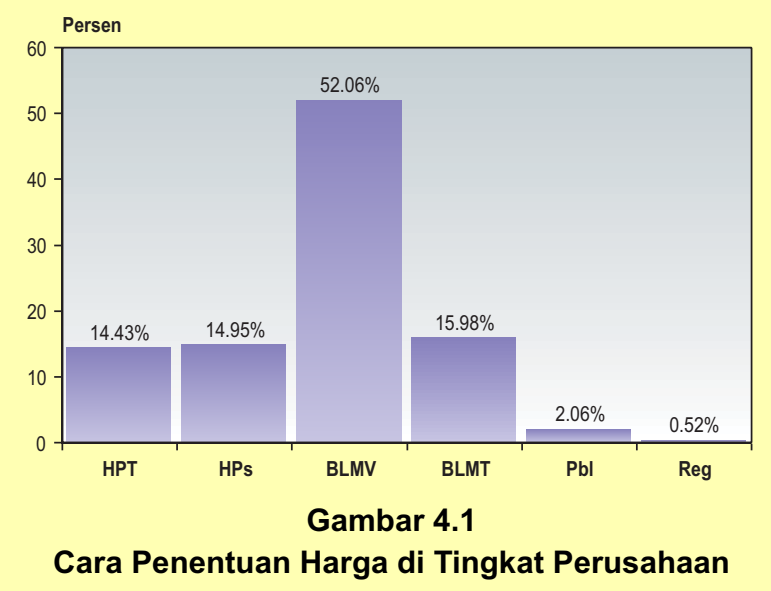

Keterangan: HPT (Harga Pokok Tertinggi), HPs (Harga Pesaing), BLMV(Biaya Langsung + Margin Variable), MLMT(Biaya Langsung + Margin Tetap), Pbl (dipengaruhi Pembeli), Reg(berdasarkan Regulasi)

Secara mayoritas pedagang besar dan ritel menyatakan bahwa metode penentuan harga yang paling banyak diadopsi adalah harga pokok pembelian ditambah margin laba. Pada umumnya pedagang tidak memiliki posisi tawar yang kuat baik terhadap produsen maupun konsumen sehingga harga jual ditentukan berdasarkan ongkos-ongkos untuk pengadaan barang. 


\begin{tabular}{|c|c|c|}
\hline \multicolumn{3}{|c|}{$\begin{array}{l}\text { Tabel } 4.1 \text {. } \\
\text { Cara penentuan harga di Tingkat Pedagang }\end{array}$} \\
\hline Cara Penentuan Harga & Grosir & Ritel \\
\hline Harga pasar tertinggi & 7.9 & 10.9 \\
\hline Harga pesaing & 11.6 & 10.9 \\
\hline Harga pokok pembelian plus margin & 75.1 & 64.4 \\
\hline Harga ditentukan pembeli & 1.6 & 2.0 \\
\hline Tawar menawar & 3.7 & 11.9 \\
\hline
\end{tabular}

\section{IV.2 Perubahan harga}

Dalam survey ini juga ditanyakan mengenai frekuensi review dan perubahan harga dalam setahun yang kemudian dicocokkan dengan perubahan-perubahan yang terjadi dalam biaya produksi dan kondisi pasar. Dalam kaitan dengan perubahan harga, review harga ternyata lebih banyak dilakukan secara tidak reguler dibanding secara reguler baik di tingkat perusahaan maupun di tingkat pedagang besar dan ritel. Review harga tampaknya dilakukan lebih atas dasar kepentingan untuk melakukan perubahan harga yang conditional terhadap faktor-faktor yang mempengaruhi harga. Kenyataan bahwa pada umumnya review tidak dilakukan secara reguler menunjukkan adanya informational menu cost yaitu biaya yang dikeluarkan untuk mengumpulkan berbagai macam informasi yang dibutuhkan untuk menentukan apakah harga yang berlaku merupakan harga yang tepat atau bukan, yang tentunya hal ini sangat berbeda dengan biaya yang harus dikeluarkan akibat perusahaan secara aktual mengimplementasikan hasil dari review tersebut. Dari sudut pandang pedagang, karena penentuan harganya lebih banyak didasarkan atas harga pokok pembelian maka review harga hanya perlu dilakukan bila terdapat perubahan dalam harga pembelian. Dengan demikian review harga secara reguler tidak begitu relevan.

Temuan dalam survey ini juga menunjukkan bahwa frekuensi perubahan harga (di luar diskon) secara aktual ternyata jarang sekali dilakukan. Perusahaan dan pedagang yang disurvey umumnya hanya melakukan perubahan harga dua kali atau kurang dalam setahun. Hal ini konsisten dengan temuan sebelumnya yaitu metoda penentuan harga yang paling dominan adalah biaya produksi ditambah mark-up variable di tingkat perusahaan dan harga pokok ditambah margin di tingkat pedagang. Perusahaan dan pedagang tampaknya lebih memilih untuk menyesuaikan tingkat margin keuntungan dibandingkan menaikkan harga ketika terjadi perubahan struktur ongkos. 

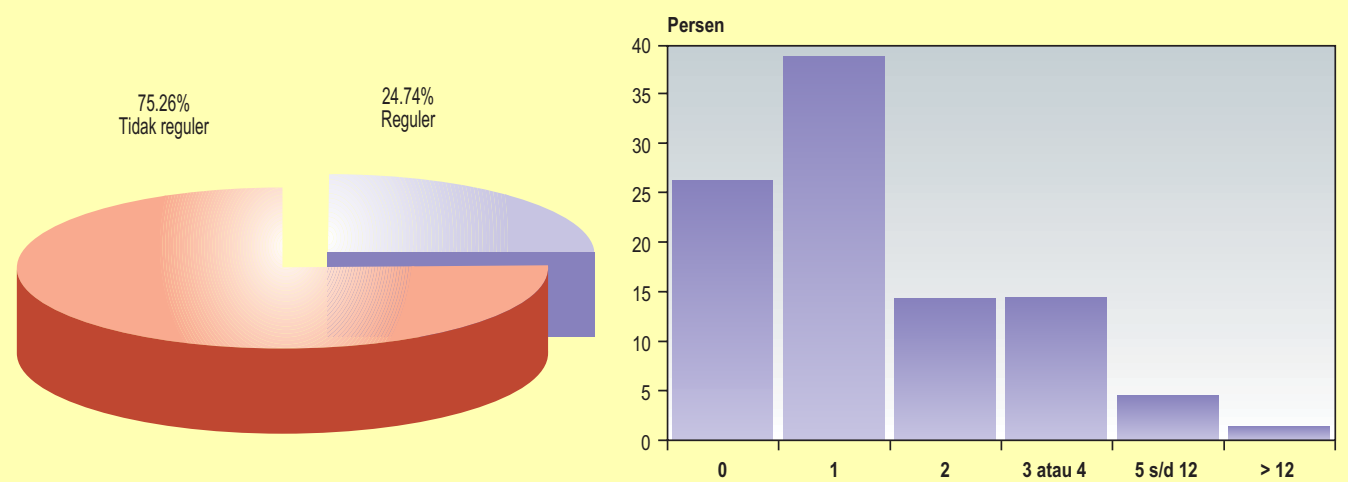

Gambar 4.2

Frekuensi dilakukannya review dan perubahan harga di tingkat produsen

\begin{tabular}{|l|c|c|}
\hline \multicolumn{2}{c}{ Tabel 4.2. } \\
\multicolumn{1}{c}{ Frekuensi dilakukannya review harga } \\
\hline Frekuensi & Grosir & Ritel \\
\hline Tidak rutin & 79.5 & 84.8 \\
Rutin: & 20.5 & 15.2 \\
\hline Harian & 0.5 & 2.0 \\
Mingguan & 4.2 & 2.9 \\
Bulanan & 10.0 & 5.9 \\
Triwulanan & 3.7 & 3.9 \\
Semesteran & 1.1 & 0.0 \\
Tahunan & 1.1 & 0.5 \\
Grand Total & 100.0 & 100.0 \\
\hline
\end{tabular}

Relatif besarnya proporsi perusahaan dan pedagang yang tidak melakukan review secara rutin dan kenyataan bahwa harga secara aktual tidak selalu sering berubah menunjukkan adanya apa yang disebut dengan informational menu costs. Menu cost semacam ini timbul karena perusahaan harus mengeluarkan biaya untuk mengumpulkan berbagai macam informasi yang dibutuhkan untuk menentukan apakah harga yang berlaku merupakan harga yang tepat atau bukan, yang tentunya hal ini sangat berbeda dengan biaya yang harus dikeluarkan akibat perusahaan secara aktual mengimplementasikan hasil dari review tersebut. Sebagai contoh, jika review harga bersifat costless maka perusahaan akan secara terus menerus menggali informasi yang dibutuhkan. Mungkin bagi perusahaan yang melakukan perubahan harga setiap hari, ekstra biaya yang dikumpulkan untuk menggali 
informasi akan lebih kecil dibanding manfaatnya. Kenyataan bahwa pada umumnya review tidak dilakukan secara reguler menunjukkan adanya informational menu cost.

\begin{tabular}{|c|c|c|}
\multicolumn{2}{c}{ Tabel 4.3. } \\
\multicolumn{1}{c|}{ Frekuensi Perubahan Harga } \\
\hline Frekuensi Perubahan Harga & Grosir & Ritel \\
\hline 0 & 22.1 & 17.6 \\
1 & 32.1 & 32.8 \\
2 & 21.6 & 23.0 \\
3 atau 4 & 9.5 & 16.7 \\
5 s/d 12 & 14.2 & 8.3 \\
$>12$ & 0.5 & 1.5 \\
& 100.0 & 100.0 \\
\hline
\end{tabular}

\section{IV.3. Faktor penyebab perubahan harga}

Untuk mengetahui sumber-sumber penyebab terjadinya inflasi, diperlukan analisis mengenai faktor-faktor yang dapat menyebabkan perusahaan melakukan perubahan harga. Penurunan harga tampaknya juga lebih sulit dilakukan dibandingkan dengan kenaikan harga. Dengan demikian perubahan harga bersifat asimetris atau terjadi apa yang disebut down ward rigidity baik ditingkat perusahaan maupun pedagang. Implikasinya adalah bahwa program disinflasi relatif lebih sulit dicapai dibandingkan dengan menciptakan inflasi.

Faktor utama yang menyebabkan perusahaan memutuskan untuk menaikkan harga adalah apabila terjadi kenaikan dalam biaya produksi langsung (90 persen). Hal ini konsisten dengan temuan terdahulu yaitu metode penentuan harga yang paling populer dilakukan diantara perusahaan adalah berdasarkan biaya produksi langsung ditambah mark up. Akan tetapi penurunan biaya produksi tidak secara otomatis akan menyebabkan turunnya harga ditingkat perusahaan. Hanya sekitar 22 persen saja yang menyatakan bahwa hal tersebut dapat terjadi. Temuan ini mengindikasikan bahwa penyumbang terbesar inflasi adalah kenaikan dalam biaya produksi, akan tetapi deflasi lebih sulit untuk diciptakan walaupun melalui penurunan biaya produksi.

Lemahnya pengaruh permintaan dan kondisi pasar terhadap harga barang manufaktur juga tercermin dari respon perusahaan terhadap perubahan permintaan. Dalam menjawab pertanyaan apabila terjadi penurunan atau kenaikan permintaan hanya sekitar 15 sampai 
17 persen perusahaan saja yang merespon perubahan tersebut melalui perubahan harga. Secara mayoritas, perusahaan lebih suka menyesuaikan tingkat produksi melalui penyesuaian jam kerja, penyesuaian jumlah pekerja, dan pemanfaatan kapasitas mesin. Hal ini berarti income effect dari suatu kebijakan moneter akan lebih banyak ditransmisikan ke tingkat output dibandingkan ke tingkat harga.

Temuan dalam bagian ini memiliki beberapa implikasi penting bagi kebijakan moneter. Pertama, penurunan tingkat inflasi akan membawa pengaruh yang cukup besar terhadap sektor riil. Kedua, pengaruh kebijakan moneter terhadap sektor riil akan menjadi lebih kuat apabila kebijakan moneter lebih banyak ditransmisikan ke sisi permintaan dibanding sisi penawaran. Dengan kata lain, agar kebijakan moneter dapat efektif maka income effectnya harus lebih besar dibanding cost effect-nya.

\begin{tabular}{|c|c|c|c|}
\hline \multicolumn{4}{|c|}{$\begin{array}{l}\text { Tabel } 4.4 \text {. } \\
\text { Respon Perusahaan Terhadap Perubahan Permintaan }\end{array}$} \\
\hline Turun & & Naik & \\
\hline Menurunkan harga & 17.1 & Menaikan harga & 15.1 \\
\hline Mengurangi produksi dg cara: & 82.9 & Menambah produksi melalui: & 84.9 \\
\hline Mengurangi lembur & 66.9 & Menaikan kerja lembur & 75.1 \\
\hline Mengurangi pekerja & 32.0 & Menambah pekerja & 49.2 \\
\hline Mengurangi kapasitas mesin & 50.8 & Meningkatkan Kapasitas mesin & 43.8 \\
\hline Mengurangi sub-kontraktor & 9.4 & Pemanfaatan perlatan menganggur & 25.9 \\
\hline
\end{tabular}

Selain faktor-faktor yang menyebabkan terjadinya perubahan harga, kepada perusahaan juga ditanyakan mengenai cara melakukan dan kecepatan penyesuaian harga apabila terdapat shock dalam biaya produksi. Sebanyak 69 persen dari responden menyatakan bahwa apabila terjadi kenaikan biaya produksi maka penyesuaian harga yang akan dilakukan adalah sebanding dengan kenaikan biaya. Sekitar 23 persen menyatakan bahwa penyesuaiannya akan lebih kecil, dan hanya 8 persen yang menyatakan bahwa penyesuaiannya akan lebih besar. Hal ini tentunya harus diinterpretasikan secara konsisten dengan temuan-temuan sebelumnya yang menunjukkan adanya bentangan biaya produksi. Hanya apabila kenaikan dalam biaya produksi telah melewati bentangan tersebut, maka harga akan disesuaikan.

Secara mengejutkan kecepatan penyesuaian harga terhadap perubahan biaya produksi dapat dilakukan secara cepat oleh perusahaan. Lebih dari 75 persen responden 
menyatakan bahwa penyesuaian harga dapat dilakukan kurang dari sebulan setelah terjadinya perubahan dalam biaya produksi. Dengan kata lain apabila kebijakan moneter secara cepat ditransmisikan ke sisi penawaran dalam bentuk perubahan struktur ongkos melalui upah dan biaya bahan baku, maka hal tersebut akan secara cepat pula diterjemahkan sebagai kenaikan atau penurunan tingkat inflasi.

Temuan ini memiliki satu implikasi yang sangat penting bagi kebijakan moneter. Agar tranmisi pengaruh kebijakan moneter setidaknya dalam jangka pendek dapat mempengaruhi tingkat output dan kesempatan kerja ada satu prasyarat yang harus dipenuhi, yaitu upah dan harga bahan baku harus bersifat kaku. Oleh karena itu transmisi moneter melalui upah, suku bunga, kredit, dan nilai tukar menjadi sangat penting.

\begin{tabular}{|c|c|c|}
\hline \multicolumn{3}{|c|}{$\begin{array}{l}\text { Tabel } 4.5 . \\
\text { Besarnya Penyesuaian Harga Terhadap Kenaikan Biaya Produksi }\end{array}$} \\
\hline & \multicolumn{2}{|c|}{ Presentase } \\
\hline Sebanding & \multicolumn{2}{|c|}{69.1} \\
\hline Lebih Kecil & \multicolumn{2}{|c|}{22.7} \\
\hline Lebih Besar & \multicolumn{2}{|c|}{8.3} \\
\hline \multicolumn{3}{|c|}{$\begin{array}{l}\text { Tabel } 4.6 \text {. } \\
\text { Kecepatan penyesuaian harga }\end{array}$} \\
\hline \multirow{2}{*}{ Response } & \multicolumn{2}{|c|}{ Perubahan Dalam Hal } \\
\hline & Biaya Produksi & Faktor Lain \\
\hline$<1$ minggu & 26.4 & 23.5 \\
\hline $1 \mathrm{~s} / \mathrm{d} 2$ minggu & 25.3 & 20.4 \\
\hline $2 \mathrm{~s} / \mathrm{d} 4$ minggu & 24.7 & 26.5 \\
\hline$>4$ minggu & 23.6 & 29.6 \\
\hline
\end{tabular}

\section{IV.4. Rigiditas Harga}

Dalam bagian-bagian terdahulu ditemukan bahwa faktor-faktor internal perusahaan dan faktor lainnya yang mempengaruhi struktur ongkos akan menentukan tingkat harga yang ditetapkan oleh perusahaan. Di level produsen dan pedagang ternyata faktor supply dan 
internal perusahaan lebih menentukan terjadinya rigiditas harga dibandingkan dengan faktorfaktor yang mencirikan perubahan kondisi pasar. Sisi supply yang mencirikan rigiditas harga adalah cost based, stock adjustment, dan physical menu cost. Di lain pihak dalam derajat yang lebih rendah, hanya dua faktor yang mencirikan sisi demand dan karakteristik pasar yang menerangkan terjadinya rigiditas harga yaitu price means quality dan coordination failure.

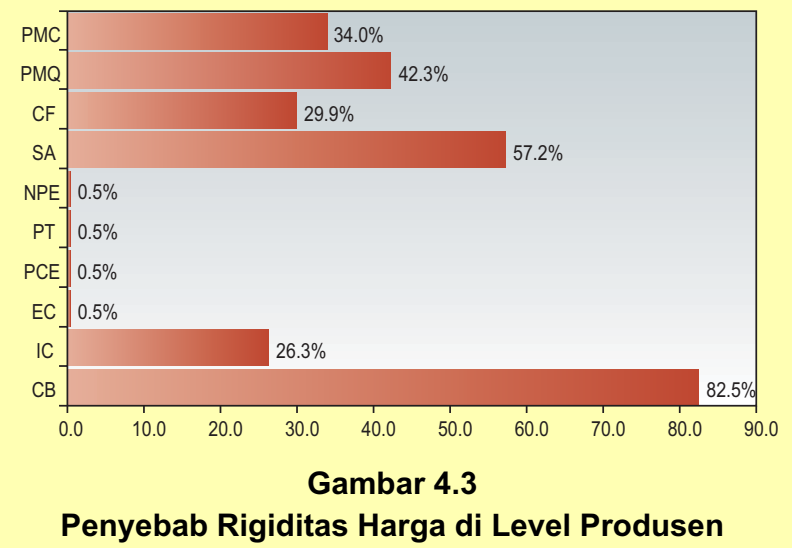

Tabel 4.7.

Sumber-sumber Rigiditas Harga di Tingkat Pedagang

\begin{tabular}{|l|c|c|} 
& Grosir & Ritel \\
\hline Harga pembelian & 84.2 & 83.8 \\
Kontrak implisit & 24.7 & 22.1 \\
Kontrak eksplisit & 23.7 & 21.1 \\
Pricing threshold & 63.7 & 55.4 \\
Penyesuaian stok & 54.2 & 41.7 \\
Kegagalan koordinasi & 18.4 & 30.9 \\
Menu cost & 24.2 & 17.2 \\
\hline
\end{tabular}

Cost based. Sebanyak kurang lebih 83 persen dari perusahaan responden menyatakan bahwa mereka enggan untuk mengubah harga kalau biaya produksi tidak berubah. Dengan kata lain mereka menerapkan cost based pricing dimana perusahaan tidak secara langsung memperhitungkan perubahan-perubahan permintaan sebagai dasar 
dalam penentuan harga. Dalam system cost based pricing, harga hanya akan berubah jika biaya upah, bahan baku serta komponen biaya lainnya telah berubah. Gordon (1981) dan Blanchard (1983) menunjukkan bagaimana cost based pricing dapat secara beruntun menyebabkan timbulnya rigiditas harga di berbagai level sisi penawaran. Jika harga output akhir bersifat kaku maka harga-harga bahan baku juga akan kaku. Jenis rigiditas harga ini ternyata berkorelasi dengan cara penentuan harga, kondisi ketenagakerjaan dan jumlah kompetitor. Perusahaan-perusahaan yang mengadopsi cara penentuan harga berdasarkan biaya produksi plus variable margin cenderung memiliki rigiditas harga ini.

Stock adjustment. Dalam menghadapi perubahan pasar perusahaan dapat menyesuaikan diri dengan cara mengubah tingkat persediaan. Dalam survey ini setidaknya terdapat 57 persen dari responden mengkonfirmasi penyesuaian tingkat persediaan. Dalam jangka pendek setidaknya perubahan dalam persediaan merupakan alternatif yang paling mudah dilakukan oleh perusahaan. Strategi penyesuaian persediaan ternyata lebih banyak diadopsi oleh perusahaan-perusahaan yang pemanfaatan kapasitas terpasangnya relatif lebih rendah, perusahaan-perusahaan yang cara penentuan harganya melalui harga tertinggi yang dapat diterima oleh pasar, serta perusahaan-perusahaan yang memiliki jangkauan pemasaran yang lebih luas.

Price means quality. Jika perusahaan berfikir bahwa pelanggan akan membeli berdasarkan price means quality, maka mereka mungkin cenderung untuk tidak melakukan penurunan harga, karena hal ini akan menimbulkan persepsi bahwa kualitas barang telah diturunkan. Quality signaling terutama berlaku untuk barang-barang mewah dan barangbarang yang sangat mempengaruhi penampilan dan kesehatan konsumennya. Dalam survey ini ditemukan bahwa sebanyak 42 persen dari responden menyatakan pentingnya quality signaling. Price mean quality cenderung berkorelasi positif dengan perusahaan-perusahaan yang memiliki ciri-ciri: (i) pangsa pasar lebih besar, (ii) produk terdiferensiasi, dan (iii) tingkat pertumbuhannya lebih tinggi. Perusahaan yang memiliki pangsa pasar lebih besar dan pertumbuhan yang lebih besar kemungkinan besar enggan menurunkan harga karena khawatir akan ditinggalkan konsumen sehingga pangsa pasar/pertumbuhannya menjadi lebih kecil.

Physical menu cost. Temuan survey menunjukkan pengaruh physical menu cost untuk perusahaan di Indonesia ternyata jauh lebih penting di banding perusahaanperusahaan di Inggris maupun di Amerika. Berdasarkan study yang dilakukan Hall, Walsh dan Yates untuk kasus Inggris ternyata hanya sekitar 7 persen saja perusahaan yang mengkonfirmasi bahwa physical menu cost penting dalam menyebabkan terjadinya rigiditas harga. Di lain pihak survey BI menunjukkan bahwa sebanyak 34 persen dari perusahaan di 
Indonesia mengkonfirmasikan hal tersebut. Ditemukan juga bahwa ternyata physical menu cost lebih penting bagi perusahaan-perusahaan yang pemanfaatan kapasitas terpasangnya lebih rendah. Tampaknya biaya ekstra yang harus dikeluarkan oleh perusahaan yang pemanfaatan kapasitas terpasangnya lebih rendah dan yang produknya terdiferensiasi dalam melakukan perubahan harga adalah lebih besar, sehingga mereka cenderung lebih enggan mengubah harga.

Co-ordination failure. Kolusi diantara perusahaan, walaupun dilakukan secara implisit, dapat menyebabkan harga bersifat kaku. Kegagalan koordinasi terjadi manakala tidak ada perusahaan yang mengambil inisiatif untuk mengubah harga sebagai respon terhadap perubahan biaya dan kondisi pasar. Perusahaan cenderung khawatir akan terjadinya perang harga yang menimbulkan konsekuensi yang lebih merugikan dibanding tidak melakukan perubahan harga sama sekali. Dalam survey ini diketemukan sekitar 30 persen perusahaan responden yang menyatakan bahwa kegagalan koordinasi adalah faktor penting yang menyebabkan rigiditas harga. Kegagalan koordinasi dianggap faktor yang lebih penting bagi perusahaan yang produksinya terdiferensiasi dibandingkan dengan perusahaan yang produknya tidak terdiferensiasi. Tampaknya hal ini konsisten dengan teori persaingan monopolistik, dimana diferensiasi produk merupakan suatu mekanisme yang diciptakan oleh perusahaan untuk mengharap relung pasar yang berbeda dengan pesaingnya.

Implicit contract. Kontrak implisit merupakan kesepakatan-kesepakatan yang tidak tertulis antara produsen dengan pelanggannnya. Kesepakatan ini adalah untuk mempertahankan konsumen-konsumen yang loyal. Mungkin kontrak implisit merupakan symptom dari rigiditas harga dan bukannya penyebab dari hal tersebut. Terjadinya kontrak implisit mungkin lebih mencirikan pertimbangan-pertimbangan lain di belakang itu seperti mempertahankan pangsa pasar, kegagalan koordinasi, price means quality dan physical menu cost. Walaupun demikian ada sekitar 26 persen responden yang menyatakan bahwa perusahaan enggan untuk mengubah harga karena terikat oleh kontrak implisit.

\section{IV.5 Respon Perusahaan terhadap Kebijakan Harga dan Upah}

Dalam survey ini pengaruh kebijakan harga dan upah terhadap tingkat harga di perusahaan juga ditanyakan. Lebih spesifiknya, pertanyaan diajukan untuk mengidentifikasi apakah kenaikan harga BBM, TDL, kebutuhan pokok dan upah buruh dan gaji PNS akan memicu perusahaan untuk menaikkan harga. Hasil dari survey ini menunjukkan bahwa hal tersebut memang terjadi. 


\section{$\underline{\text { Administered price }}$}

Yang dimaksud dengan administered price adalah harga yang ditetapkan melalui peraturan pemerintah. Contoh klasiknya adalah harga BBM, TDL, dan harga pulsa telepon. Kenaikan dalam administered price biasanya menyebabkan perusahaan yang memproduksi barang lainnya ikut meningkatkan harga. Alasannya ada dua hal. Pertama, adalah announcement effect dimana perusahaan memanfaatkan moment kenaikan administered price sebagai alasan untuk menaikkan harga. Perusahaan dapat mengkambinghitamkan pemerintah sebagai pemicu kenaikkan harga dan karenanya perusahaan dapat terhindar dari konsekuensi negatif yang ditimbulkan oleh kenaikkan harga. Kedua, adalah pengaruh administered price terhadap struktur ongkos perusahaan.

Dalam survey ini sekitar 76 persen responden menyatakan bahwa harga barang yang dihasilkan oleh perusahaan akan dinaikkan kalau pemerintah mengumumkan kenaikkan dalam administered price. Hal ini sangat menyedihkan karena jika benar maka effek dari administered price terhadap inflasi akan cukup besar. Implikasinya, pengendalian terhadap inflasi akan cenderung memberatkan posisi fiskal pemerintah. Untuk menahan agar administered price tidak meningkat, pemerintah dihadapkan pada kenyataan bahwa subsidi harus ditingkatkan, misalnya dalam kasus subsidi BBM.

Selain itu, temuan ini menunjukan bahwa posisi fiskal sangat menentukan tingkat inflasi. Pada saat dimana pemerintah melakukan konsolidasi fiskal dengan cara pemotongan subsidi, harga barang-barang akan cenderung meningkat. Karena itu, pengendalian inflasi tidak hanya cukup melalui kebijakan moneter tetapi juga harus dibantu melalui kebijakan fiskal. Pentargetan inflasi hanya bisa secara efektif dilakukan bila kebijakan fiskal dan moneter bersinergi.

\section{Upah minimum}

Upah minimum adalah tingkat upah yang ditetapkan melalui peraturan pemerintah tentang jumlah upah terkecil yang harus diberikan oleh perusahaan di wilayah tertentu. Sebagaimana halnya administered price, kenaikan dalam upah minimum memiliki dua dampak yaitu anouncement effect dan cost effect.

Dalam survey ini ditemukan setidaknya terdapat 53 persen responden yang menyatakan akan meningkatkan harga jika pemerintah menaikkan tingkat upah minimum. Implikasi bagi kebijakan moneter dari temuan ini akan menjadi sangat penting ketika penyesuaian dalam upah minimum dikaitkan dengan tingkat inflasi. Apabila hal ini terjadi maka peran kebijakan moneter dalam mempengaruhi kesempatan kerja dan tingkat pengangguran akan berkurang. 
Karena upah minimum menjadi salah satu faktor terpenting yang menentukan harga di tingkat perusahaan, cara penentuan upah minimum akan sangat berpengaruh terhadap persistensi inflasi. Indeksasi upah minimum terhadap inflasi secara back ward looking akan menyebabkan inflasi yang bersifat persisten. Namun jika indeksasi dilakukan terhadap target inflasi yang ditetapkan otoritas moneter, harga-harga barang akan cenderung mengikuti target tersebut.

\section{$\underline{\text { Harga sembako }}$}

Kenaikkan dalam harga kebutuhan pokok dapat memiliki pengaruh terhadap perusahaan-perusahaan lainnya. Setidaknya ada 42 persen responden yang menyatakan akan menaikkan harga jika terjadi kenaikan harga kebutuhan pokok. Hal ini terjadi mungkin karena dua hal berikut ini. Pertama, kenaikan harga sembako menyebabkan harga relatif yang dihadapi oleh perusahaan menjadi lebih tidak menguntungkan sehingga untuk mencegah hal tersebut perusahan akan memandang perlu kenaikan harga. Kedua, kenaikan harga sembako terutama akan berpengaruh secara negatif bagi kelompok berpendapatan rendah dimana buruh termasuk di dalamnya. Hal ini akan mengakibatkan buruh menuntut upah yang lebih tinggi, dan untuk mengantisipasi ini perusahaan dapat menaikan harga.

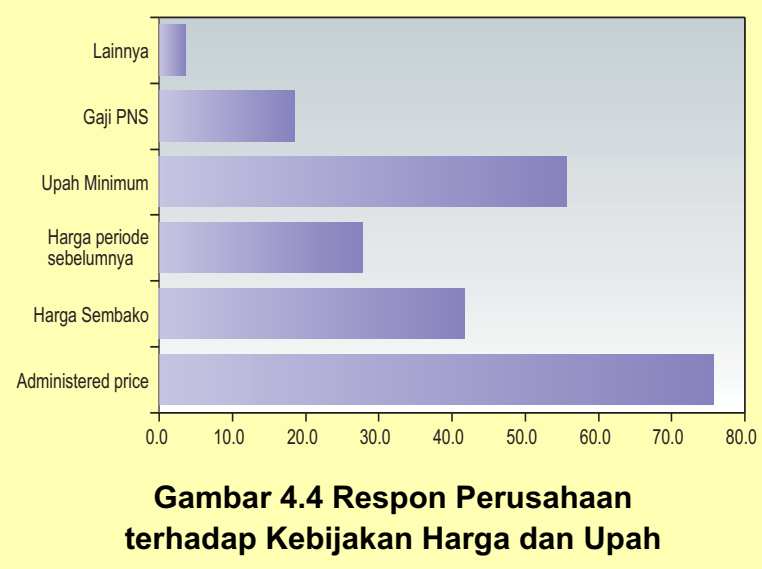

\section{IV.6. Ekspektasi Inflasi}

Dalam survei ini juga didapatkan bukti yang konsisten tentang pembentukan ekspektasi inflasi di tingkat perusahaan dan pedagang. Perusahaan dan pedagang mengidentifikasi tiga sumber utama peningkatan ekspektasi inflasi yaitu administered price, harga sembako 
dan nilai tukar (tabel $4.9 \& 4.10$ ). Selain itu mayoritas responden perusahaan menyatakan bahwa inflasi berperan penting dalam proses penentuan harga. Hal ini berarti tingkat harga ditentukan tidak hanya berdasarkan struktur ongkos tetapi juga berdasarkan harga relatif terhadap harga barang-barang lainnya. Implikasinya adalah, pengendalian inflasi di tingkat makro akan memiliki pengaruh terhadap besarnya kenaikan harga di tingkat perusahaan dan pedagang. Dengan demikian pentargetan inflasi hanya akan efektif bila target tersebut bersifat kredibel.

\begin{tabular}{l|c|c}
\multicolumn{2}{c}{ Tabel 4.9. } \\
\multicolumn{2}{c}{ Pembentukan Ekspektasi Inflasi di Tingkat Perusahaan } \\
\cline { 2 - 3 } & \multicolumn{2}{|c}{ Naik } \\
\hline Administered price & 94.8 & Turun \\
Harga Sembako & 74.7 & 64.9 \\
Harga Periode Sebelumnya & 39.2 & 57.2 \\
Suku bunga & 42.3 & 0.0 \\
Nilai Tukar & 63.4 & 0.5 \\
Upah Minimum & 0.5 & 49.5 \\
Gaji PNS & 41.8 & 0.0 \\
Lainnya & 0.5 & 0.0 \\
\end{tabular}

Mayoritas perusahaan dan pedagang ternyata merespon secara konsisten terhadap perubahan dalam nilai tukar. Depresiasi akan mengakibatkan kenaikan harga dan sebaliknya apresiasi akan diterjemahkan menjadi penurunan harga. Hal ini tidaklah mengejutkan mengingat komoditas manufaktur merupakan tradable goods.

Selain itu, perusahaan memandang penting inflasi sebagai bahan pertimbangan dalam memutuskan kenaikan harga (Gambar 4.5). Hanya sekitar 37 persen yang memandang hal tersebut tidak penting. Ekspektasi inflasi dengan demikian menjadi hal penting dalam menentukan besar kecilnya inflasi aktual. Dari survey didapatkan gambaran bahwa 56 persen ekspektasi inflasi dibentuk berdasarkan atas prakiraan inflasi sekarang. Prakiraan yang paling banyak dipakai adalah yang bersumber dari Bank Indonesia dan BPS. Oleh karena itu sangat penting bagi kedua intitusi tersebut untuk mensinkronkan prakiraan inflasi dan dilakukan secara lebih terukur. 
Tabel 4.10.

Ekspektasi Inflasi di Tingkat Pedagang

\begin{tabular}{|l|c|c|}
\hline \multicolumn{1}{|c|}{ Pengaruh dari } & Grosir & Ritel \\
\hline Administered price & 91.1 & 89.2 \\
Harga Sembako & 69.5 & 74.0 \\
Harga Periode Sebelumnya & 30.0 & 28.4 \\
Suku bunga & 31.1 & 26.0 \\
Nilai Tukar & 52.1 & 45.6 \\
Upah Minimum & 42.1 & 41.2 \\
Gaji PNS & 23.2 & 32.8 \\
Lainnya & 1.1 & 0.5 \\
\hline
\end{tabular}

\section{DINAMIKA PEMBENTUKAN DAN RIGIDITAS UPAH}

Analisis mengenai dinamika pembentukan upah biasanya meliputi empat hal yaitu: (i) wage setting stance, (ii) wage scheme, (iii) wage change, dan (iv) wage rigidity. Analisis mengenai wage setting stance difokuskan untuk mengetahui bagaimana proses penentuan upah di tingkat perusahaan. Analisis mengenai wage scheme bertujuan untuk mengetahui struktur upah yang berlaku di perusahaan. Selain itu perlu juga diketahui mengenai faktorfaktor yang menyebabkan terjadinya kenaikan atau penurunan tingkat upah, baik secara riil maupun nominal (wage change). Akhirnya suatu analisis mengenai dinamika pembentukan upah harus juga dilengkapi dengan analisis mengenai faktor-faktor yang menyebabkan terjadinya rigiditas upah (wage rigidity).

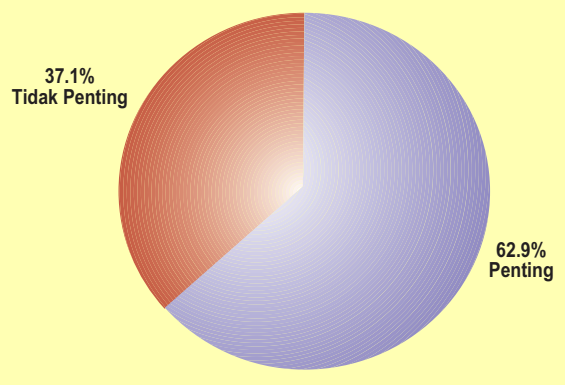

Gambar 4.5

Pentingnya Inflasi dalam Penentuan Harga 


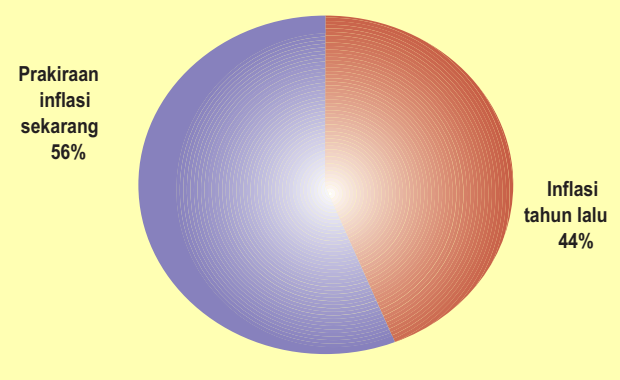

Gambar 4.6.

Dasar Penentuan Inflasi

\section{V.1. Cara Penentuan Upah (Wage Setting Stance)}

Mayoritas responden (80.1\%) menyatakan bahwa cara penentuan upah di perusahaan didasarkan atas regulasi pemerintah (Tabel 5.1). Regulasi pemerintah dalam penentuan upah di Indonesia adalah dalam penentuan Upah Minimum Propinsi (UMP). Hal ini menunjukkan bahwa kebanyakan perusahaan hanya berusaha untuk memenuhi upah yang ditetapkan secara minimum oleh pemerintah. Di sisi lain, $71.4 \%$ dari responden menyatakan bahwa upah ditentukan berdasarkan implicit contract. Dalam kasus seperti ini baik pekerja maupun perusahaan biasanya mengacu pada suatu tingkat upah yang berlaku secara umum di lingkungan sekitarnya atau dalam jenis pekerjaan yang serupa. Contoh yang paling tepat mengenai hal ini adalah penentuan upah di sektor konstruksi dimana upah kuli bangunan cenderung seragam di suatu daerah tertentu tanpa adanya kontrak yang eksplisit dan masing-masing pihak bersepakat untuk mengikuti skema pengupahan yang berlaku umum. Di lain pihak, hanya $37.8 \%$ responden yang menentukan upah berdasarkan explicit contract. Berarti lebih banyak responden yang menggunakan implicit contract daripada explicit contract.

Dari hasil tersebut juga tampak bahwa responden lebih menentukan upah berdasarkan individual bargaining (40.8\%) dibandingkan dengan union bargaining (26.5\%). Dan 39.3\% dari responden menyatakan bahwa upah ditentukan berdasarkan efficiency wage, di mana responden perusahaan secara sengaja menentukan tingkat upah yang lebih tinggi dibanding dengan perusahaan lain untuk jenis pekerjaan yang sama. Hal ini dimaksudkan untuk mendorong motivasi kerja yang lebih baik dan untuk mempertahankan pekerja yang memiliki produktivitas tinggi. 
Cara Penentuan Upah (Wage Setting Stance)

\begin{tabular}{|l|c|}
\multicolumn{1}{c}{ Wage Setting Stance } & Presentase Responden \\
\hline Individual bargaining & $40.8 \%$ \\
Union bargaining & $26.5 \%$ \\
Regulasi & $80.1 \%$ \\
Implicit contract & $71.4 \%$ \\
Explicit contract & $37.8 \%$ \\
Efficiency wage & $39.3 \%$ \\
\end{tabular}

\section{V.2. Skema Pengupahan (Wage Scheme)}

Dengan skema pengupahan berdasarkan gaji tetap saja, upah biasanya dihitung secara mingguan atau bulanan. Skema ini biasanya berlaku untuk pekerja tetap. Mayoritas responden menyatakan bahwa skema pengupahan yang digunakan adalah dengan gaji tetap dan gaji ditambah insentif. Dan hanya $17.86 \%$ yang menyatakan bahwa skema pengupahan ditentukan berdasarkan produktivitas (Tabel 5.2) .

\begin{tabular}{l|r}
\multicolumn{2}{c}{ Tabel 5.2. } \\
Skema Pengupahan \\
\multicolumn{1}{c|}{ Skema Pengupahan } & Presentase \\
Gaji tetap saja & $29.59 \%$ \\
Gaji plus insentif & $33.16 \%$ \\
Upah harian & $19.39 \%$ \\
Upah berdasarkan produktivitas & $17.86 \%$ \\
Grand Total & $\mathbf{1 0 0 . 0 0 \%}$ \\
\hline
\end{tabular}

\section{V.3. Penyesuaian Upah (Wage Change)}

Dalam jangka panjang tingkat upah baik secara nominal maupun riil cenderung berubah. Setidaknya ada tujuh faktor yang dapat mengakibatkan terjadinya perubahan upah yaitu (i) pengalaman kerja, (ii) perubahan gaji di dalam industri sejenis, (iii) regulasi, (iv) biaya hidup/ inflasi (v) tuntutan Serikat Buruh, (vi) keuntungan perusahaan, (vii) produktivitas karyawan (Tabel 5.3). Ternyata mayoritas responden (48\%) menyesuaikan upah karena faktor regulasi pemerintah. Hal ini konsisten dengan jawaban responden untuk 
cara penentuan upah (wage setting stance) pada Sub. 5.1. di mana memang mayoritas responden $(80.1 \%)$ menentukan upah berdasarkan regulasi pemerintah.

\begin{tabular}{l|c}
\multicolumn{2}{c}{ Tabel 5.3. } \\
\multicolumn{1}{c}{ Faktor-faktor Yang Mempengaruhi Perubahan Tingkat Upah } \\
\multicolumn{1}{|c}{ Penyesuaian Upah } & Presentase \\
\hline Pengalaman kerja & $38.3 \%$ \\
Perubahan gaji di industri sejenis & $10.7 \%$ \\
Regulasi & $48.0 \%$ \\
Biaya hidup/inflasi & $16.3 \%$ \\
Tuntutan Serikat Buruh & $9.2 \%$ \\
Keuntungan perusahaan & $14.3 \%$ \\
Produktivitas karyawan & $14.3 \%$ \\
Lainnya & $9.2 \%$ \\
\hline
\end{tabular}

Saat terjadi kenaikan harga kebutuhan pokok sebanyak $59.2 \%$ responden menyatakan karyawannya tidak menuntut kenaikan upah (Tabel 5.4).

\begin{tabular}{|c|c|}
\hline Tindakan Karyawan & Presentase \\
\hline Karyawan menuntut kenaikan upah & $40.8 \%$ \\
\hline Tidak ada tuntutan & $59.2 \%$ \\
\hline
\end{tabular}

Hampir semua responden, atau $98.5 \%$ responden memilih tetap mempertahankan tingkat upah nominal saat terjadi penurunan pada harga-harga barang (deflasi) (Tabel 5.5).

\begin{tabular}{|c|c|}
\hline \multicolumn{2}{|c|}{$\begin{array}{l}\text { Tabel } 5.5 . \\
\text { Tindakan Perusahaan Jika Terjadi Deflasi }\end{array}$} \\
\hline Tindakan Perusahaan & Presentase \\
\hline Upah nominal diturunkan & $1.5 \%$ \\
\hline Upah nominal tetap & $98.5 \%$ \\
\hline
\end{tabular}


Sebanyak $81.6 \%$ responden menganggap bahwa manfaat penurunan upah lebih kecil dibanding konsekuensi negatif yang ditimbulkannya (Tabel 5.6).

\begin{tabular}{l|c|}
\multicolumn{1}{c}{ Persepsi Penurunan Upah } \\
\hline \multicolumn{1}{c|}{ Persepsi Penurunan Upah } & Presentase \\
\hline $\begin{array}{l}\text { Manfaatnya lebih kecil dibanding } \\
\text { konsekuensi negatifnya }\end{array}$ & $81.6 \%$ \\
\hline $\begin{array}{l}\text { Manfaatnya lebih besar dari } \\
\text { konsekuensi negatifnya }\end{array}$ & $3.8 \%$ \\
\hline $\begin{array}{l}\text { Manfaatnya sebanding dengan } \\
\text { konsekuensi negatifnya }\end{array}$ & $14.65 \%$ \\
\hline
\end{tabular}

\section{V.4. Rigiditas Upah (Wage Rigidity)}

Hasil survei kepada responden mengenai rigiditas upah dirangkum dalam tabel berikut ini :

\begin{tabular}{l|c}
\multicolumn{2}{c}{ Tabel 5.7. } \\
\multicolumn{1}{c}{ Sumber Penyebab Rigiditas Upah } \\
\hline \multicolumn{1}{c}{ Sumber Regiditas Upah } & Presentase \\
\hline (i)Explicit contract & $37.8 \%$ \\
(ii)Implicit contract & $71.4 \%$ \\
(iii)Efficiency wage & $39.3 \%$ \\
(iv)Insider-outsider & $13.78 \%$ \\
(v)Menu cost & $77.04 \%$ \\
(vi)Non wage adjustment & $73.0 \%$ \\
(vii)Asymmetric information & $38.8 \%$ \\
(viii)Downward rigidity & $87.76 \%$
\end{tabular}

Jawaban mayoritas untuk pertanyaan sumber rigiditas upah adalah:

- Downward wage rigidity

Dari tabel tersebut tampak bahwa $87.76 \%$ dari responden menyatakan bahwa terjadi 
downward wage rigidity. Ini adalah suatu indikasi terjadinya downward wage rigidity.

- Menu cost

Dari tabel tersebut tampak bahwa $77.04 \%$ dari responden menyatakan bahwa sumber rigiditas upah berasal dari menu cost

- Non wage adjustement

Ternyata $73 \%$ responden menyatakan bahwa sumber rigiditas upah berasal dari non wage adjustment. Mereka lebih baik melakukan penyesuaian selain upah daripada menyesuaikan upah.

- Implicit contract

Dari tabel tersebut tampak bahwa $71.4 \%$ menyatakan bahwa sumber rigiditas upah berasal dari implicit contract.

\section{KESIMPULAN DAN IMPLIKASI KEBIJAKAN}

\section{VI.1. Kesimpulan}

Dalam hal penentuan harga, secara umum bisa dikatakan bahwa faktor-faktor yang menyangkut biaya perusahaan atau sisi supply jauh lebih berperan dibanding kondisi pasar atau sisi demand. Penentuan harga di tingkat perusahaan berdasarkan biaya langsung ditambah mark up variable merupakan metoda yang paling dominan. Konsisten dengan hal tersebut penentuan harga di tingkat pedagang besar dan ritel juga didominasi oleh harga pokok pembelian ditambah margin. Implikasinya adalah bahwa secara makro sumber inflasi yang paling besar adalah dari sisi supply.

Penentuan harga berdasarkan biaya produksi juga tampaknya lebih dominan pada perusahaan berskala menengah besar, produknya terdiferensiasi dan memiliki jangkauan pemasaran yang lebih luas. Dengan demikian pengaruh perubahan struktur ongkos akan lebih dirasakan oleh perusahaan dalam kategori tersebut. Sementara itu, pengaruh perubahan pasar akan lebih dirasakan oleh perusahaan berskala kecil, berorientasi pada pasar lokal dan produknya tidak terdiferensiasi.

Dalam kaitan dengan perubahan harga, review harga ternyata lebih banyak dilakukan secara tidak reguler dibanding secara reguler baik di tingkat perusahaan maupun di tingkat pedagang besar dan ritel. Review harga tampaknya dilakukan lebih atas dasar kepentingan untuk melakukan perubahan harga yang conditional terhadap faktor-faktor yang mempengaruhi harga. Kenyataan bahwa pada umumnya review tidak dilakukan secara 
reguler menunjukkan adanya informational menu cost yaitu biaya yang dikeluarkan untuk mengumpulkan berbagai macam informasi yang dibutuhkan untuk menentukan apakah harga yang berlaku merupakan harga yang tepat atau bukan, yang tentunya hal ini sangat berbeda dengan biaya yang harus dikeluarkan akibat perusahaan secara aktual mengimplementasikan hasil dari review tersebut. Dari sudut pandang pedagang, karena penentuan harganya lebih banyak didasarkan atas harga pokok pembelian maka review harga hanya perlu dilakukan bila terdapat perubahan dalam harga pembelian. Dengan demikian review harga secara reguler tidak begitu relevan.

Temuan dalam survey ini juga menunjukkan bahwa frekuensi perubahan harga (di luar diskon) secara aktual ternyata jarang sekali dilakukan. Perusahaan dan pedagang yang disurvey umumnya hanya melakukan perubahan harga dua kali atau kurang dalam setahun. Hal ini konsisten dengan temuan sebelumnya yaitu metoda penentuan harga yang paling dominan adalah biaya produksi ditambah mark-up variable di tingkat perusahaan dan harga pokok ditambah margin di tingkat pedagang. Perusahaan dan pedagang tampaknya lebih memilih untuk menyesuaikan tingkat margin keuntungan dibandingkan menaikkan harga ketika terjadi perubahan struktur ongkos.

Penurunan harga tampaknya juga lebih sulit dilakukan dibandingkan dengan kenaikan harga. Dengan demikian perubahan harga bersifat asimetris atau terjadi apa yang disebut down ward rigidity baik ditingkat perusahaan maupun pedagang. Implikasinya adalah bahwa program disinflasi relatif lebih sulit dicapai dibandingkan dengan menciptakan inflasi.

Faktor utama yang menyebabkan perusahaan memutuskan untuk menaikkan harga adalah apabila terjadi kenaikan dalam biaya produksi langsung. Pengaruh kondisi pasar tampaknya tidak sekuat pengaruh biaya produksi. Karena itu kebijakan moneter akan menjadi lebih efektif apabila income effect-nya lebih kuat dibandingkan dengan cost effect-nya.

Di tingkat pedagang besar dan ritel penyebab terjadinya perubahan harga yang paling utama adalah terjadinya perubahan dalam harga pokok pembelian. Secara mayoritas penyesuaian harga yang dilakukan oleh pedagang adalah sebanding dengan kenaikan harga pembelian. Namun demikian terdapat perbedaan dalam kecepatan penyesuaian harga. Waktu yang dibutuhkan oleh pedagang ritel untuk menyesuaikan harga pada umumnya kurang dari seminggu. Di lain pihak penyesuaian harga di tingkat pedagang besar berlangsung kurang dari dua minggu sedangkan di tingkat perusahaan memerlukan waktu yang agak lebih lama yaitu kurang dari sebulan.

Studi ini juga berupaya mengidentifikasi sumber-sumber terjadinya rigiditas harga. Dalam studi ini ditunjukan bahwa ternyata sisi supply factor dan internal perusahaan lebih 
menentukan terjadinya rigiditas harga dibandingkan dengan faktor-faktor yang mencirikan perubahan kondisi pasar. Sisi supply yang mencirikan rigiditas harga adalah cost based, stock adjustment, dan physical menu cost. Di lain pihak dalam derajat yang lebih rendah, hanya dua faktor yang mencirikan sisi demand dan karakteristik pasar yang menerangkan terjadinya rigiditas harga yaitu price means quality dan coordination failure. Implikasinya adalah bahwa terjadinya rigiditas harga memerlukan prasyarat adanya rigiditas upah dan rigiditas dalam harga bahan baku.

Rigiditas harga di tingkat pedagang besar dan ritel sedikit agak berbeda dibanding di tingkat perusahaan. Tiga faktor utama penyebab rigiditas harga di tingkat pedagang adalah harga pembelian, pricing threshold, dan penyesuaian stok. Faktor-faktor permintaan dan kondisi pasar tampaknya juga kurang bisa menerangkan rigiditas harga di tingkat pedagang.

Dalam survei ini juga didapatkan bukti yang konsisten tentang pembentukan ekspektasi inflasi di tingkat perusahaan dan pedagang. Perusahaan dan pedagang mengidentifikasi tiga sumber utama peningkatan ekspektasi inflasi yaitu administered price, harga sembako dan nilai tukar. Selain itu mayoritas responden perusahaan menyatakan bahwa inflasi berperan penting dalam proses penentuan harga. Hal ini berarti tingkat harga ditentukan tidak hanya berdasarkan struktur ongkos tetapi juga berdasarkan harga relatif terhadap harga barang-barang lainnya. Implikasinya adalah, pengendalian inflasi di tingkat makro akan memiliki pengaruh terhadap besarnya kenaikan harga di tingkat perusahaan dan pedagang. Dengan demikian pentargetan inflasi hanya akan efektif bila target tersebut bersifat kredibel.

Mayoritas perusahaan dan pedagang ternyata merespon secara konsisten terhadap perubahan dalam nilai tukar. Depresiasi akan mengakibatkan kenaikan harga dan sebaliknya apresiasi akan diterjemahkan menjadi penurunan harga. Hal ini tidaklah mengejutkan mengingat komoditas manufaktur merupakan tradable goods. Yang terlebih penting lagi adalah bahwa mayoritas perusahaan memandang pentingnya stabilitas nilai tukar. Hal ini mungkin disebabkan oleh pengalaman buruk yang dialami selama krisis dimana nilai tukar sangat sulit untuk dikendalikan. Volatilitas nilai tukar dipandang sebagai salah satu sumber ketidakpastian dan instabilitas.

\section{VI.2. Implikasi Kebijakan}

\section{(i) Efektifitas Kebijakan Moneter}

Cost based pricing yang merupakan metoda penentuan harga yang paling umum diadopsi perusahaan dan cost based price rigidity memiliki implikasi yang luas bagi kebijakan 
moneter terutama menyangkut efektifitas kebijakan moneter dan pentargetan inflasi. Setidaknya ada beberapa hal penting yang perlu dicermati.

Agar bisa efektif, kebijakan moneter yang dipilih sebaiknya adalah yang efeknya terhadap struktur ongkos bersifat minimum. Pengaruh kebijakan moneter terhadap struktur ongkos dapat dibagi menjadi tiga saluran; expected inflation, nilai tukar, dan suku bunga. Kebijakan yang bersifat ekspansioner dapat menyebabkan terjadinya depresiasi yang pada gilirannya dapat menaikan harga-harga produk manufacturing melalui peningkatan harga bahan baku yang diimpor. Kebijakan tersebut juga dapat meningkatkan ekspektasi inflasi baik secara langsung melalui sisi permintaan agregat maupun secara tidak langsung melalui peningkatan harga barang-barang tradable. Di lain pihak ongkos perusahaan bisa jadi turun melalui penurunan pembayaran bunga atas kredit perbankan. Oleh karena itu efek bersih suatu kebijakan moneter terhadap struktur ongkos perusahaan sangat tergantung pada besaran efek nilai tukar dan ekspektasi inflasi yang berbanding terbalik dengan efek dari suku bunga. Perlu suatu kajian lanjutan mengenai interaksi dari ketiga efek tersebut sehingga ada bukti secara kuantitatif tentang bagaimana kebijakan moneter mempengaruhi struktur ongkos perusahaan.

Dari sisi permintaan agregat, kebijakan moneter diperkirakan dapat efektif secara penuh karena harga relatif kurang dipengaruhi oleh kondisi permintaan. Apabila suatu kebijakan moneter dapat secara efektif mempengaruhi permintaan agregat, maka pada gilirannya perubahan permintaan agregat tersebut akan lebih banyak berpengaruh terhadap output dan persediaan dibandingkan terhadap harga.

\section{(ii) Asimetri efek kebijakan moneter}

Terjadinya asimetri dalam pergerakan harga dan faktor-faktor yang mempengaruhinya mencirikan bahwa harga lebih kaku ke bawah. Selain itu upah nominal juga bersifat rigid ke bawah. Karena itu, kebijakan moneter yang bersifat kontraktif akan memiliki efek yang lebih besar dibanding kebijakan yang bersifat ekspansif. Oleh karenanya, perlu kehati-hatian yang lebih tinggi dalam mengimplementasikan kebijakan yang bersifat kontraktif.

\section{(iii) Pentargetan inflasi}

Pentargetan inflasi tampaknya akan mengalami hambatan terutama karena ekspektasi inflasi lebih didominasi oleh variable-variable yang berada di luar jangkauan otoritas moneter yaitu: administered price dan harga sembako. Artinya, kebijakan moneter 
mungkin tidak cukup untuk mengarahkan inflasi ke arah yang diinginkan. Kebijakan fiskal dan perdagangan memiliki pengaruh yang cukup kuat terhadap inflasi. Dengan demikian perlu adanya upaya sinkronisasi kebijakan antara otoritas moneter dan otoritas fiskal dan perdagangan.

Namun demikian, jika pentargetan inflasi bisa dengan sempurna memperhitungkan pengaruh kebijakan fiskal dan perdagangan, kredibilitas pentargetan inflasi akan semakin membaik. Hal ini disebabkan oleh fakta bahwa mayoritas responden dalam pembentukan ekspektasi inflasi semakin bersifat rasional. Prakiraan inflasi sekarang (forecast) yang diterbitkan oleh BI dan BPS dijadikan reference utama oleh responden dalam memperkirakan tingkat inflasi aktual. Dalam jangka panjang jika forecast BI dan BPS bisa terbukti mendekati inflasi aktual, pentargetan inflasi akan bersifat credible.

\section{(iv) Upah minimum}

Kebijakan upah minimum merupakan salah satu variable yang paling berpengaruh terhadap ekspektasi inflasi. Jika upah minimum diindeksasi terhadap inflasi tahun sebelumnya maka inflasi akan bersifat persisten dan dengan demikian kebijakan untuk menekan inflasi akan lebih sulit untuk dilakukan. Oleh karenanya, perlu dibuat suatu konsensus agar upah tidak diindeksasi terhadap inflasi sebelumnya. Namun jika upah minimum diindeksasi dengan pra-kiraan inflasi yang ditargetkan oleh $\mathrm{BI}$, maka pentargetan inflasi tampaknya akan berlangsung lebih mulus. 


\section{DAFTAR PUSTAKA}

Bernanke, Ben dan Alan S. Blinder. (1995), “The Federal Fund Rate and the Channels of Nonetary Transmission, “American Economic Review, Vol 82 (September) : 901 -21

Blinder, A. (1991), “ Why Prices Sticky?”. Preliminary result from an interview study, American Economic Review, pages 89-96.

Caplin, A and Spulber, D (1987), “ Menu Cost and The Neutrality of Money”, Quartely Journal of Economics, 102, pages $703-25$.

Chairi, V., P. Kehoe,. And E. McGrattan. (1998). Monetary shocks and real exchange rate in sticky price models of international business cycles. Federal Reserve Bank of Minneapolis Research Departement Staf Report No. 223

Cozier, Barry (1991).“Wage and Price Dynamics in Canada”, Paper Bank of canada, November.

Darsono, Akhis R, dkk, (2002), "Survey on Business Price Setting Behavior", CIRET Conference, Taipei, Oktober

Dighe, Ranjit S, (1998), "A Helicopter Tour of Competing Theories of Wage Rigidity, As Applied to the Great Depression", Working paper of SUNY Oswego, Economics Departement, Oswego

Dornbusch, Rudiger, Stanley Fisher, Richard Startz. (1998), Macroeconomics, 7 th edition, New York : McGraw-Hill.

Falch, T. and B. Strom (1990), “ Local Flexibility in wage setting : Evidence from the Norwegian Local Public Sector", Norwegian University of Science and Tehnology, Norway

Gordon, Donald F. (1974) "A Neo Classical Theory of Keynesian Unemployment," Economic Inquiry (12) : $431-459$

Groshen, Erica L (1997), "The Effects of Inflation on Wage Adjustments in FirmLevel Data : Grease or Sand?. “, Federal Reserve bank of New York, November

Hall, S, M.Walsh, and A.Yates, (1997) “ How do UK Companies Set Price?”, Bank of England, Working Paper Series No. 67, July 
Hess, D. Gregory ( 1999) “Does Wage Inflation Cause Price Inflation ?", Wall Street Journal, September 3, 1999

Huang, X.D Kevin,(1999) “ Staggered Price, Staggered wage - Setting, and Business Cycle Persistence", Departement of Economics, Utah State University, Logan, USA

Kasuya, Munehisa (1999), "Downward Price Rigidity of Japanese CPI - Analysis by Probability Density Functions and Spatial Density Functions”, Research and Statistics Department, Bank of Japan, Working paper Series 99-3, August

Lee, F (1995) "From post- Keynesian to historical price theory, part 2", Review of Political Economy, 7.1 ( 72-124).

Mankiew, N.Gregory. (2000). Macroeconomics, 4 th edition, New York : World Publisher, Harvard University.

Mishkin, Frederic S. (1986). The Economic of Money, Banking, and Financial Market, First edition, Columbia University.

Nakagawa, S, H. Ryota, and T. Izumi (1999) "Price-Setting Behavior of Japanese Companies", Research and Statistics Department, Bank of Japan, Working paper, August

Petursson, G T.(2002), "Wage and Price Formation in a Small open Economy : Evidence from Iceland", working papers no. 16, Economics Departement, Central Bank of Iceland, March

Romer, David. (1996), Advanced Macroeconomics, Firts edition, New York : McGrawHill. 